\title{
Hubungan Dukungan Suami dengan Kelengkapan Kunjungan ANC di Puskesmas Lubuk Buaya
}

\author{
Inge De Laila $S^{1}$, Ida Rahmah Burhan², Tuti Handayani ${ }^{3}$ \\ ${ }^{1}$ Fakultas Kedokteran Universitas Andalas, Padang \\ ${ }^{2}$ Bagian IImu Kesehatan Masyarakat Fakultas Kedokteran Universitas Andalas, Padang \\ ${ }^{3}$ Bagian Radiologi Fakultas Kedokteran Universitas Andalas, Padang
}

\section{A B S T R A C T}

\begin{abstract}
Latar Belakang. Melakukan kunjungan ANC sesuai standar merupakan salah satu cara untuk meningkatkan status kesehatan ibu hamil dalam rangka menurunkan angka kematian ibu di Indonesia. Cakupan ANC di Puskesmas Lubuk Buaya yang belum mencapai target dalam dua tahun terakhir, menggambarkan bahwa masih ada ibu hamil yang tidak melakukan kunjungan ANC sesuai standar. Keterlibatan suami selama kehamilan dapat menjadi faktor pendorong untuk memeriksakan kehamilan.
\end{abstract}

Objektif. Penelitian ini bertujuan untuk mengetahui hubungan dukungan suami terhadap kelengkapan kunjungan ANC ibu hamil di Puskesmas Lubuk Buaya.

Metode. Penelitian ini adalah penelitian analitik menggunakan desain cross sectional dan dianalisis dengan menggunakan uji chi-square. Teknik pengambilan sampel yang digunakan dalam penelitian ini adalah consecutive sampling dengan jumlah sampel sebanyak tiga puluh enam orang ibu hamil yang berkunjung ke Puskesmas Lubuk Buaya dari bulan Januari 2019 - Februari 2019 dengan usia kandungan $\geq$ tiga puluh enam minggu. Data diambil menggunakan kuesioner untuk menilai dukungan suami.

Hasil. Sebanyak $52.8 \%$ ibu hamil melakukan ANC lengkap sesuai standar (K4). Dukungan suami baik pada ibu hamil ditemukan sebanyak $61.1 \%$ dari total responden Berdasarkan dari hasil penelitian terdapat hubungan antara dukungan suami dengan kelengkapan kunjungan ANC ( $=0.003)$.

Kesimpulan. Adanya hubungan yang signfikan antara dukungan suami dengan kelengkapan kunjungan ANC. Untuk itu tenaga kesehatan perlu memberikan informasi dan pendidikan tentang kesehatan ibu hamil tidak hanya kepada ibu hamil tetapi juga kepada suaminya.

Kata kunci: kunjungan ANC, K4, dukungan suami

Background. Conducting ANC visits according to standards is one way to improve the health status of pregnant women in order to reduce maternal mortality in Indonesia. The coverage of the ANC at the Lubuk Buaya Health Center has not reached its target in the past two years. This illustrates that there are still pregnant women who don't make ANC visits according to standards. Husband's involvement during pregnancy can be a reinforcing factor in ANC visits. This study discussed the characteristics of elderly patients who received the first chemotherapy in RSUP dr. M. Djamil Padang.
Objective. This study aims to determine the relationship between husband's support for the completeness of ANC visits for pregnant women at Lubuk Buaya Health Center.

Method. This research is an observational descriptive study with a cross sectional design. This study is an analytical study using a cross sectional design and analyzed by using the Chisquare test. Consecutive sampling was used, with a total objects of 36 pregnant women who visited the Lubuk Buaya Health Center from January in 2019 untill February in 2019 with a gestational age $\geq 36$ weeks. Data were taken by using a questionnaire to assess husband's support.

Result. A total of $52.8 \%$ of pregnant women had complete ANC according to standard (K4). Good husband support for pregnant women found $61.1 \%$ of the total respondents. There are statistically significant correlation between husband's support and the completeness of ANC visits ( $p=0.003$ ).

Conclusion. For this reason, health workers need to provide information and education about the maternal health during pregnancy not only to pregnant women, but also to their husbands.

Keywords. ANC visits, K4, husband's support

\section{Apa yang sudah diketahui tentang topik ini?}

Kunjungan ANC dipengarui oleh tingkat pengetahuan, sikap, peran keluarga serta peran bidan.

\section{Apa yang ditambahkan pada studi ini?}

Dukungan suami termasuk faktor yang memperkuat terjadinya perubahan perilaku/reinforcing factors.

\section{CORRESPONDING AUTHOR}

Name: Inge De Laila $S$

Phone: +6282288100673

E-mail:delailainge@gmail.com

ARTICLE INFORMATION

Received: September $23^{\text {rd }}$, 2020

Revised: October $15^{\text {th }}, 2020$

Available online: October $31^{\text {st }}$, 2020 


\section{Pendahuluan}

Komplikasi selama kehamilan, persalinan dan pascamelahirkan merupakan penyebab utama kematian dan kecacatan di kalangan wanita usia reproduksi di negara berkembang. Angka kematian ibu merupakan risiko yang terkait dalam setiap kehamilan, yaitu risiko obstetri. ${ }^{1}$ Meningkatkan kesehatan ibu merupakan indikator Millenium Development Goals poin ke lima dan terkait dalam tujuan ketiga didalam Sustainable Development Goals. Indikator ini berguna untuk memonitor hal-hal yang berhubungan dengan kehamilan dan persalinan. ${ }^{2}$ Berdasarkan data dari WHO, kematian ibu akibat komplikasi selama kehamilan dan persalinan telah menurun $43 \%$ dari perkiraan 532.000 pada tahun 1990 menjadi 303.000 pada tahun 2015.1 Penurunan AKI per tahun kurang dari setengah persen yang diharapkan untuk mencapai target Millenium Development Goals. ${ }^{3}$

Salah satu cara meningkatkan derajat kesehatan ibu hamil adalah memperkuat Antenatal Care (ANC), yaitu pelayanan kesehatan yang diberikan oleh tenaga kesehatan kepada ibu hamil yang dilaksanakan sesuai standar pelayanan kebidanan. ${ }^{4}$ Hal ini membawa ibu hamil lebih dekat ke tenaga kesehatan dan meningkatkan peluangnya untuk bertahan hidup. ${ }^{5}$ Persyaratan minimal frekuensi jumlah kunjungan pelayanan ibu hamil di tiap trimester, yaitu satu kali pada trimester pertama (usia kehamilan 0-12 minggu), satu kali pada trimester kedua (usia kehamilan 12-24 minggu), dan dua kali pada trimester ketiga (usia kehamilan 24-36 minggu). Standar waktu pelayanan tersebut dianjurkan untuk menjamin perlindungan terhadap ibu hamil dan atau janin berupa deteksi dini faktor risiko, pencegahan, dan penanganan dini komplikasi kehamilan. ${ }^{6}$

Indikator $\mathrm{K} 1$ ideal dan $\mathrm{K} 4$ adalah indikator untuk melihat frekuensi yang merujuk pada periode trimester saat melakukan pemeriksaan kehamilan. ${ }^{7}$ Cakupan K1 adalah jumlah ibu hamil yang telah memperoleh pelayanan antenatal pertama kali oleh tenaga kesehatan dibandingkan jumlah sasaran ibu hamil di satu wilayah kerja pada kurun waktu satu tahun. Sedangkan cakupan K4 adalah jumlah ibu hamil yang telah memperoleh pelayanan antenatal sesuai dengan standar paling sedikit empat kali sesuai jadwal yang dianjurkan di tiap trimester dibandingkan jumlah sasaran ibu hamil di satu wilayah kerja pada kurun waktu satu tahun. Indikator tersebut memperlihatkan tingkat kepatuhan ibu hamil dalam memeriksakan kehamilannya ke tenaga kesehatan. ${ }^{6}$

Cakupan K1 dan K4 di Indonesia dari tahun 2015 sampai 2017 terlihat sedikit penurunan dalam cakupan K4 yaitu dari 87,48\% menjadi 86,57\%. Pada tahun 2017 didapatkan sebelas provinsi yang pencakupan K4 nya dibawah target, termasuk Sumatera Barat dengan cakupan K4 sebesar 74,09\%.8 Dalam kurun waktu tiga tahun terakhir 2015-2017 cakupan K4 di Sumbar mengalami penurunan dari $89,9 \%$ menjadi 74,09\%. ${ }^{9}$ Secara umum, dalam 2 tahun ini program K4 di Padang sudah mencapai target yaitu $95 \%{ }^{10}$ Peneliti masih menemukan Puskesmas di Kota Padang yang cakupan K1 dan K4 nya masih dibawah target, yaitu Puskesmas Lubuk Buaya. Berdasarkan laporan tahunan Dinas Kesehatan Kota Padang, tercatat penurunan cakupan K1 dari 92.5\% menjadi $87.9 \%$ dan K4 dari $87.9 \%$ ke $82.2 \%$.

Ada banyak faktor yang berperan didalam kelengkapan kunjungan ANC, diantaranya tingkat pengetahuan, sikap, peran keluarga serta peran bidan. Berdasarkan hasil penelitian yang dilakukan oleh Fitrayeni dkk tahun 2015, didapatkan $63 \%$ responden memiliki tingkat pengetahuan rendah, $67,4 \%$ memiliki sikap negative dan $58,7 \%$ responden menyatakan suami tidak mendukung. Untuk itu diperlukan upaya untuk meningkatkan peran dan dukungan suami agar ibu hamil dapat melaksanakan kunjungan ANC dengan lengkap. ${ }^{11}$

Keterlibatan suami dalam kunjungan antenatal dan kesiapan mereka dalam menghadapi kasus darurat juga diperlukan disamping pengetahuan dan kesadaran suami tentang kebutuhan fisik, emosional dan sosio-ekonomi dari istri mereka yang hamil. ${ }^{12}$ Hal ini didukung oleh teori perubahan perilaku menurut Lawrence Green, perilaku seseorang terhadap pelayanan kesehatan dipengaruhi oleh tiga faktor utama yaitu predisposing factors, enabling factors, dan reinforcing factors. Dukungan suami termasuk faktor yang memperkuat terjadinya perubahan perilaku/reinforcing factors. ${ }^{13}$ Berdasarkan masalah tersebut, penulis ingin melakukan penelitian mengenai hubungan dukungan suami terhadap kelengkapan kunjungan ANC ibu hamil di Puskesmas Lubuk Buaya. 


\section{Metode}

Jenis peneltian ini adalah analitik obervasionaL dengan desain penelitian cross sectional. Penelitian dilakukan di Puskesmas Lubuk Buaya Kota Padang yang dimulai sejak September 2018 Februari 2019. Populasi pada penelitian ini adalah seluruh ibu hamil yang bertempat tinggal di wilayah Puskesmas Lubuk Buaya pada tahun 2018-2019.

Sampel dalam penelitian ini berjumlah 35 ibu hamil dengan teknik pengambilan sampel yaitu concecutive sampling yaitu setiap ibu hamil yang berkunjung ke Puskesmas dan memenuhi kriteria inklusi dan tidak termasuk dalam kriteria eksklusi diwawancara sampai jumlah sampel minimal terpenuhi.

Data diperoleh dengan cara wawancara menggunakan kuesioner yang berupa daftar pernyataan tertulis dengan skala likert yang digunakan untuk mengetahui dukungan suami. Data Kunjungan ANC diperoleh dari buku KIA. Data dianalisis secara statistik menggunakan analisis Chi-square.

\section{Hasil}

Penelitian ini dilaksanakan di Puskesmas Lubuk Buaya pada bulan Januari 2019-Februari 2019. Populasi pada penelitian ini adalah seluruh ibu hamil yang bertempat tinggal di wilayah Puskesmas Lubuk Buaya. Sampel yang digunakan pada penelitian ini berjumlah 36 orang dengan teknik pengambilan sampel consecutive sampling dengan memilih ibu hamil dengan usia kehamilan $\geq 36$ minggu yang memenuhi kriteria inklusi dan eksklusi sampai didapatkan jumlah sampel minimal.

\section{Karakteristik Responden}

Tabel 1. Karakteristik Responden Ibu Hamil usia Kehamilan $\geq 36$ Minggu

\begin{tabular}{|c|c|c|c|}
\hline Data Demografi & f & $\%$ & $\begin{array}{c}\text { ANC } \\
\text { lengkap }\end{array}$ \\
\hline \multicolumn{4}{|l|}{ Usia (tahun) } \\
\hline$<20$ tahun & 0 & 0,00 & 0 \\
\hline 20-35 tahun & 31 & 86,1 & 17 \\
\hline >35 tahun & 5 & 13,9 & 2 \\
\hline \multicolumn{4}{|l|}{ Pendidikan Terakhir } \\
\hline $\mathrm{SD}$ & 1 & 2,8 & 0 \\
\hline SMP & 6 & 16,7 & 3 \\
\hline SMA/SMK & 14 & 38,9 & 7 \\
\hline D3 & 3 & 8,3 & 2 \\
\hline $\mathrm{S} 1$ & 8 & 22,2 & 4 \\
\hline Lain-lain & 4 & 11,1 & 3 \\
\hline
\end{tabular}

\begin{tabular}{lccc}
\hline \multicolumn{1}{c}{ Data Demografi } & $\mathbf{f}$ & $\mathbf{\%}$ & $\begin{array}{c}\text { ANC } \\
\text { lengkap }\end{array}$ \\
\hline Pekerjaan Ibu & & & \\
$\quad$ Ibu Rumah Tangga & 25 & 69,4 & 11 \\
$\quad$ PNS & 2 & 5,6 & 2 \\
$\quad$ Pegawai Swasta & 3 & 8,3 & 2 \\
$\quad$ Wirausaha & 2 & 5,6 & 1 \\
$\quad$ Lain-lain & 4 & 11,1 & 3 \\
Jumlah Paritas & & & \\
$\quad<2$ & 25 & 69,4 & 16 \\
$\quad 2$ & 11 & 30,6 & 3 \\
\hline Jumlah & 36 & 100 & 19 \\
\hline
\end{tabular}

Berdasarkan tabel 1 responden terbanyak berada pada kelompok umur 20-35 tahun (86,1\%). Pendidikan terakhir responden terbanyak pada tingkatan SMA (38.9\%), pekerjaan yang dominan dikalangan responden adalah ibu rumah tangga (69.4\%). Lebih dari separuh jumlah paritas responden terbilang sedikit yaitu <2 $(69,4 \%)$.

\section{Distribusi Frekuensi Kunjungan ANC (K1\&K4)}

K1

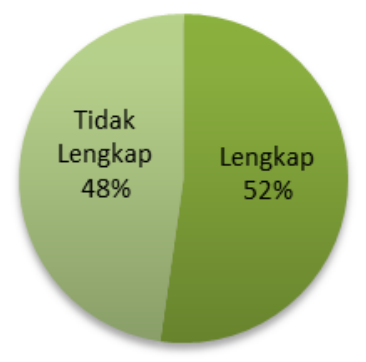

K4

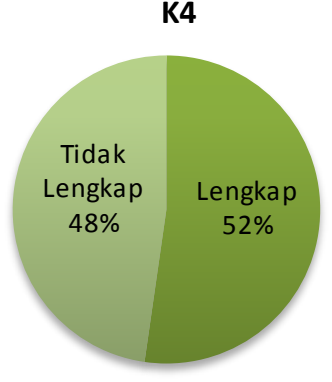

Gambar 1. Distribusi Frekuensi Kunjungan ANC (K1\&K4)

Berdasarkan gambar 1 dari total sampel 36 orang ibu hamil dengan usia kehamilan $\geq 36$ minggu, didapatkan bahwa sebanyak 52,8 \% ibu hamil mendapat pelayanan kesehatan minimal $1 \mathrm{x}$ pada waktu kehamilan trimester pertama (K1). Ibu hamil yang memiliki kunjungan ANC lengkap sesuai standar (K4) sebanyak $52,8 \%$ dari total responden. Hasil penelitian menunjukkan bahwa 
seluruh ibu yang melakukan ANC tidak lengkap, tidak berkunjung pada waktu trimester awal kehamilan.

\section{Distribusi Distribusi Frekuensi Dukungan Suami}

\section{Dukungan Suami}

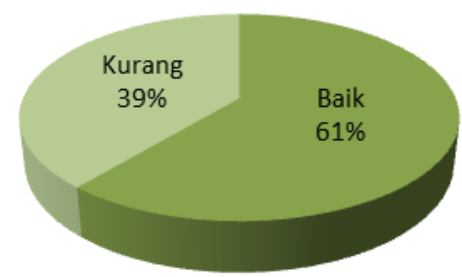

Gambar 2. Distribusi Frekuensi Dukungan Suami

Berdasarkan gambar 2 ditemukan 61,1\% ibu hamil mendapatkan dukungan yang baik dari suaminya selama kehamilan.

\section{Hubungan Dukungan Suami dengan Kelengkapan Kunjungan ANC}

\begin{tabular}{|c|c|c|c|c|c|c|c|}
\hline \multicolumn{5}{|c|}{$\begin{array}{ll}\text { Tabel 2. Hubungan Dukungan } \\
\text { Kelengkapn Kujungan ANC }\end{array}$} & \multicolumn{2}{|c|}{ Suami } & erhadap \\
\hline \multirow{3}{*}{$\begin{array}{l}\text { Dukungan } \\
\text { suami }\end{array}$} & \multicolumn{4}{|c|}{$\begin{array}{c}\text { Kelengkapan } \\
\text { Kunjungan ANC }\end{array}$} & \multirow{2}{*}{\multicolumn{2}{|c|}{ Total }} & \multirow{3}{*}{$\begin{array}{c}\mathbf{p} \\
\text { value }\end{array}$} \\
\hline & \multicolumn{2}{|c|}{ Lengkap } & \multicolumn{2}{|c|}{$\begin{array}{c}\text { Tidak } \\
\text { Lengkap }\end{array}$} & & & \\
\hline & $\mathrm{f}$ & $\%$ & $\mathrm{f}$ & $\%$ & $F$ & $\%$ & \\
\hline Baik & 16 & 72,7 & 6 & 27,3 & 22 & 100 & \\
\hline Kurang & 3 & 21,4 & 11 & 78,6 & 14 & 100 & 0,003 \\
\hline Total & 19 & 52,8 & 17 & 47,2 & 36 & 100 & \\
\hline
\end{tabular}

Berdasarkan tabel 2, didapatkan bahwa sebanyak $72,7 \%$ responden yang mendapatkan dukungan baik dari suami melakukan kunjungan ANC secara lengkap dibandingkan dengan responden yang kurang mendapat dukungan suami, hanya 27,3 \% yang melakukan kunjungan ANC lengkap. Hasil penelitian ini didapatkan $p$ value $<0,05$ yaitu sebesar 0,003 yang artinya terdapat hubungan antara dukungan suami dengan kelengkapan kunjungan ANC.

\section{Pembahasan}

\section{Distribusi Frekuensi Kelengkapan Kunjungan ANC (K1\&K4)}

Berdasarkan hasil penelitian yang didapatkan lebih dari separuh jumlah ibu hamil yang memiliki ANC lengkap sesuai standar sebanyak 19 orang atau $52,8 \%$ dari total responden, sedangkan ibu hamil data kunjungan ANC tidak lengkap sebanyak $47,2 \%$ atau 17 orang dari 36 responden. Hasil penelitian yang dilakukan oleh Ika tahun 2012 di Depok, ibu hamil yang melakukan kunjungan ANC teratur ditemukan sebanyak 90,2\% dari total responden, sedangkan yang tidak melakukan ANC tidak teratur sebanyak 9,8\%. Faktor-faktor yang mempengaruhi kunjungan ANC dalam penelitian ini salah satunya adalah paritas yang sedikit. ${ }^{14}$ Lebih dari separuh jumlah responden dengan paritas yang sedikit $(<2)$ juga didapatkan dalam penelitian ini sebanyak 69,4\%.

Hal ini sesuai dengan hasil penelitian yang dilakukan Elsa Gebri Utami di Puskesmas Sungayang tahun 2017, sebanyak 68,3\% ibu hamil melakukan kunjungan ANC lengkap sesuai standar. Ibu hamil yang berkunjung kebanyakan berumur 20-35 tahun, rata-rata tingkat pendidikan responden yaitu tamatan SMA, dan sebagian besar ibu hamil tidak bekerja. ${ }^{15}$ Karakteristik responden yang sama didapatkan dalam hasil penelitian ini, yaitu responden terbanyak berada pada kelompok umur 20-35 tahun $(86,1 \%)$. Pendidikan terakhir responden terbanyak pada tingkatan SMA (38.9\%), pekerjaan yang dominan dikalangan responden adalah ibu rumah tangga (69.4\%).

Hasil penelitian ini menunjukkan bahwa seluruh ibu hamil yang tidak melakukan ANC secara lengkap, tidak melakukan kunjungan pada trimester awal kehamilan. Pemeriksaan pada awal kehamilan sangat penting untuk memberi informasi pada ibu hamil mengenai pemilihan makanan selama kehamilan karena pada trimester awal terjadi tahapan organogenesis yang membutuhkan nutrisi yang adekuat. Ibu hamil yang tidak melakukan kunjungan diawal kehamilan akan melewatkan pemeriksaan ANC dan edukasi dari tenaga kesehatan, sehingga halhal yang dapat menjadi penyulit dalam kehamilan dan persalinan tidak terdeteksi sejak awal. ${ }^{16}$

Persyaratan minimal frekuensi jumlah kunjungan pelayanan ibu hamil di tiap trimester, yaitu satu kali pada trimester pertama (usia kehamilan 0-12 minggu), satu kali pada trimester kedua (usia kehamilan 12-24 minggu), dan dua kali pada trimester ketiga (usia kehamilan 24-36 minggu). ${ }^{6}$ Kelengkapan kunjungan ANC pada ibu hamil dipengaruh oleh faktor internal dan eksternal. ${ }^{17}$ Faktor internal berasal dari dalam diri ibu hamil seperti usia, paritas, tingkat pendidikan, sikap, dan pengetahuan ibu. Faktor eksternal yaitu 
faktor yang berasal dari lingkungan sekitar meliputi pelayanan fasilitas kesehatan, media informasi, jarak tempat tinggal, peran bidan dan dukungan suami. ${ }^{13}$

\section{Distribusi Frekuensi Dukungan Suami}

Hasil distribusi frekuensi dukungan suami ibu hamil yang berkunjung ke Puskesmas Lubuk Buaya didapatkan bahwa 22 orang atau sebanyak $61,1 \%$ responden mendapatkan dukungan yang baik dari suaminya. Ditemukan 38,9 \% ibu hamil yang kurang mendapat dukungan suami yaitu 14 orang dari 36 total responden. Berdasarkan penelitian Rismawati yang dilakukan di Makassar tahun 2012 didapatkan dukungan suami yang mendukung sebanyak $86,7 \%$ dan yang tidak mendukung sebanyak $13,3 \%$ dari 35 total responden. ${ }^{18}$ Hal ini juga sejalan dengan penelitian yang dilakukan oleh A.A Marsita tahun 2015 di Pontianak didapatkan hasil yang lebih tinggi yaitu $85 \%$ atau 65 dari 80 ibu hamil mendapatkan dukungan suami yang baik. ${ }^{19}$

Indonesia mencanangkan program Suami SIAGA (Siap, Antar, Jaga) dan Pencegahan Komplikasi (P4K). Program-program ini menunjukkan pentingnya partisipasi keluarga dalam kehamilan dan persalinan. ${ }^{20}$ Oleh karena itu para suami diharapkan untuk membahas masalah-masalah terkait kehamilan dan berpartisipasi aktif selama pemeriksaan kehamilan,persalinan dan nifas. ${ }^{21}$ Bentuk dari dukungan suami yang dilihat didalam penelitian ini ada empat jenis, yaitu dukungan informasional, penilaian, emosional dan instrumental. ${ }^{22}$

\section{Hubungan Dukungan Suami terhadap Kelengkapan ANC}

Berdasarkan hasil penelitian, terdapat $61,1 \%$ ibu hamil yang mendapat dukungan yang baik dari suami. Pada ibu hamil yang mendapat dukungan suami yang baik, 72,7 \% melakukan ANC lengkap dan 27,3 \% tidak melakukan ANC lengkap. Ibu hamil dengan dukungan suami yang baik namun tidak melakukan ANC lengkap sebagian besar bekerja sebagai ibu rumah tangga. Persentase ibu hamil dengan dukungan suami kurang didapatkan 38,9\%, yang melakukan kunjungan ANC lengkap sebanyak 21,4 \% dan yang melakukan ANC tidak lengkap sebanyak 78,6\%. Ibu yang tetap melakukan ANC lengkap walaupun suami kurang mendukung sebagian besar berpendidikan tinggi (minimal SMA). Data ini menunjukkan bahwa ibu hamil yang mendapatkan dukungan yang baik dari suami memiliki persentase yang lebih besar dalam melakukan kunjungan ANC secara lengkap yang secara statistik menunjukkan hubungan yang bermakna dengan $p$-value $<0.05$ yaitu sebesar 0,003 .

Hasil penelitian yang dilakukan oleh A.A Marsita di Makassar tahun 2015 terhadap 80 ibu hamil, didapatkan adanya hubungan antara dukungan suami dengan kelengkapan kunjungan ANC dengan $p$-value sebesar 0,003.19 Penelitian yang dilakukan oleh Ni Nyoman tahun 2013 di Bali terhadap 69 responden menunjukkan bahwa terdapat hubungan dukungan keluarga dengan cakupan pelayanan antenatal. Dengan uji regresi logistik dengan $\mathrm{p}=0,03 \quad(\mathrm{p}<0,05)$ dimana ibu dengan dukungan keluarga yang tinggi memiliki cakupan ANC 8 kali lebih tinggi dari ibu yang memiliki dukungan keluarga rendah. ${ }^{23}$

Hasil penelitian ini sesuai dengan teori, bahwa dukungan suami termasuk kedalam faktor pendorong terjadinya perubahan perilaku, yaitu melakukan kunjungan ANC.13 Dalam menjalani kehamilan dan persiapan kelahiran tidak hanya semata-mata urusan wanita tetapi juga suami. Hasil penelitian Anna Kurniati dkk tahun 2017 di Indonesia menunjukkan bahwa adanya signifikansi dari hubungan suami SIAGA dengan pemanfaatan layanan kesehatan ibu sehingga hal ini dapat mewujudkan target pemerintah untuk menurunkan angka kematian ibu di Indonesia. ${ }^{20}$ Selain dukungan suami yang merupakan faktor eksternal, masih ada faktor internal yang mempengaruhi seperti pekerjaan dan pendidikan. ${ }^{17}$ Ibu yang berpendidikan tinggi akan semakin tinggi tingkat kepedulian terhadap kebutuhannya selama hamil dan semakin baik pola pikirnya terhadap kesehatan. sehingga walaupun ibu tidak mendapat dukungan suami yang baik, akan tetap pergi melakukan ANC. ${ }^{24}$

\section{Simpulan}

Berdasarkan hasil penelitian ini didapatkan kesimpulan sebagai berikut: Lebih dari separuh ibu hamil sudah melakukan kunjungan pada trimester awal kehamilan dan melakukan kunjungan ANC secara lengkap sesuai waktu yang ditentukan. Lebih dari separuh ibu hamil $(61,1 \%)$ mendapatkan dukungan yang baik dari suami 
selama kehamilan. Terdapat hubungan antara dukungan suami dengan kelengkapan kunjungan ANC di Puskesmas Lubuk Buaya.

\section{Ucapan Terima Kasih}

Penulis telah banyak mendapat bantuan dari berbagai pihak, oleh karena itu penulis mengucapkan terima kasih kepada .seluruh pihak yang telah mendukung dan memberikan arahan kepada penulis,. Kepada Kepala Puskesmas Lubuk Buaya dan penanggung jawab bagian KIA yang telah memberikan izin melaksanakan penelitian .

\section{Daftar Pustaka}

1. World Health Organization. Trends in maternal mortality: 1990 to 2015. estimates by WHO, UNICEF, UNFPA, World Bank Group and the United Nations Population Division. Geneva; 2015.

2. United Cities and Local Government Asia Pacific. Tujuan Pembangunan Berkelanjutan yang Perlu Diketahui oleh Pemerintah Daerah. UCLG. Jakarta; 2017.

3. World Health Organization. Millenium of Development Goals (MDGs) [Internet]. WHO. 2015. https://www.who.int/topics/millennium_developme nt_goals/maternal_health/en/ - Diakses September 2018.

4. Direktorat Jenderal Bina Kesehatan Masyarakat. Pedoman Pemantauan Wilayah Setempat Kesehatan Ibu dan Anak (PWS-KIA). Jakarta; 2010.

5. Akowuah JA, Agyei-Baffour P, Awunyo-Vitor D. Determinants of antenatal healthcare utilisation by pregnant women in third trimester in peri-urban Ghana. J Trop Med. 2018;2018:8.

6. Kementrian Kesehatan Republk Indonesia. Profil Kesehatan Indonesia Tahun 2015. Jakarta; 2016.

7. Departemen Kesehatan Republik Indonesia. Riset kesehatan dasar (2013). Jakarta; 2013.

8. Kementrian Kesehatan Republk Indonesia. Profil Kesehatan Indonesia 2017. Jakarta; 2018.

9. Dinas Kesehatan Provinsi Sumbar. Profil Kesehatan Provinsi Sumatera Barat Tahun 2016. Padang; 2017.

10. Dinas Kesehatan Kota Padang. Profil Kesehatan Kota Padang tahun 2017. Padang; 2018.

11. Fitrayeni, Suryati, Faranti RM. Penyebab Rendahnya Kelengkapan Kunjungan Antenatal Care Ibu Hamil Di Wilayah Kerja Puskesmas Pegambiran. J Kesehat Masy Andalas. 2015;10(1):101-7.

12. Sokoya M, Rn, Bnsc, Farotimi A, Ojewole, Foluso. Women's perception of husbands' support during pregnancy, labour and delivery. IOSR J Nurs Heal Sci Ver I. 2014;3:45-50.

13. Notoadmojo S. Promosi Kesehatan Teori dan Aplikasinya. Jakarta: Rineka Cipta; 2010. p. 43-7.

14. Priani IF. Faktor-faktor yang mempengaruhi keteraturan ibu hamil melakukan kunjungan Antenatal Care di Puskesmas Ciamis Kota Depok (Skripsi). Fakultas Keperawatan. Universitas Indonesia; 2012.

15. Utami GE. Faktor-faktor yang Berhubungan dengan Kunjungan Antenatal Care di Wilayah Kerja Puskesmas Sungayang Kab.Tanah Datar tahun 2017
(Skripsi). Fakuktas Kedokteran. Universitas Andalas; 2017.

16. Departemen Kesehatan RI. Pedoman Perencanaan Persalinan dan Pencegahan Komplikasi (P4K) dengan Stiker. Jakarta; 2009.

17. Notoadmojo S. Promosi Kesehatan dan Perilaku Kesehatan. Jakarta: Rineka Cipta; 2012. p. 45-62.

18. Rismawati, Suhartatik, Sjafaraenan. Hubungan Dukungan Suami Dengan Motivasi Ibu Hamil Terhadap Pemeriksaan Antenatal Care di RSKDIA Siti Fatimah Makassar Tahun 2012. 2013;2(1):1-8.

19. Marsita AA. Hubungan Tingkat Pengetahuan dan Dukungan Suami Terhadap Kunjungan Antenatal Care di Wilayah Kerja Puskesmas Perumnas II. 2015;1-18.

20. Kurniati A, Chen C, Efendi F, Ku LE, Berliana SM. Suami SIAGA: male engagement in maternal health in Indonesia. 2017;32(8)1-9.

21. Maternal and Neonatal Health Program of Johns Hopkins University. Mobilizing for Impact: Indonesia's SIAGA Campaign Promotes Shared Responsibility. Baltimore; 2004.

22. Friedman MM. Keperawatan keluarga: Riset, teori dan praktik. In Jakarta: EGC; 2010. p. 168-70.

23. Nyoman N, Agustini M, Suryani N, Murdani P. Hubungan antara Tingkat Pengetahuan Ibu dan Dukngan Keluarga dengan Cakupan Pelayanan Antenatal di Wilayah Kerja Puskesmas Buleleng I. Jurnal Magister Kedokteran Keluarga. 2013;1(1):6779.

24. Yenita A, Shigeko H. Factors influencing the use of antenatal care in rural West Sumatra, Indonesia. BMC Pregnancy Childbirth. 2012;12(9):8. 